\title{
Research Notice: Real Estate Knowledge and the Development of a Real Estate Curricula for African Universities
}

\author{
Rachel Mirembe ${ }^{1}$, and François Viruly ${ }^{2}$ \\ 1-2 Urban Real Estate Research Unit, Department of Construction Economics, University of \\ Cape Town
}

To cite this article: Mirembe, R. \& Viruly, F. (2018). Real Estate Knowledge and Real Estate Curricula in African Universities. Journal of African Real Estate Research, 3(2), pp.9-17. DOI: 10.15641/jarer.v3i2.692.

\begin{abstract}
Real estate education across the globe has, at its core, certain universal and value-neutral skills and knowledge. This knowledge has developed over decades to reflect the functions of specific market structures which characterise real estate markets. Moreover, it is reflective of the maturity of real estate markets, and as such, the tools developed reflect specific market structures. Real estate analysts are becoming increasingly interested in real estate markets in emerging economies. The challenge facing these analysts is that the dominant real estate theory is based on mature markets within an industrialised context and therefore do not accurately reflect real estate markets in emerging economies. The generic context of real estate markets in emerging economies tends to be characterised by a dual economy, a lack of transparency in the markets, high levels of uncertainty and the existence of communal/customary and informal rights in the ownership of real estate. Hence, this study examines the real estate academic syllabus taught by universities in Sub-Saharan Africa. In doing so this ongoing research aims to assess and understand the differences that exist between the real estate programmes and examine the direction that these programmes could take in an emerging country context.
\end{abstract}

Keywords: Real Estate Education; Real Estate Curricula; Emerging Economies; Sub-Saharan Africa

\section{Introduction}

Over the years, there have been calls to standardise the real estate curricula, but due to the dynamic nature of real estate, this has not been achieved (Kampamba, Tembo, \& Nkwae, 2017). As a result, it has become increasingly difficult to define a singular body of knowledge for real estate education (Black \& Rabianski, 2003). There are differences not only reflected in the international divergence of real estate education, but also in real estate 
practice and the contextual organisation of the profession (Boyd, Amidu, \& Smith, 2014). This can be evidenced by the differences in programme names, the structure of programmes and curricula content at various universities. As a result, where one chooses to pursue real estate studies will, to a very large degree, determine the type of education they receive. For example, if one pursues a real estate degree in the United States, one will most likely get a comprehensive exposure to the multiple disciplines of business (Black \& Rabianski, 2003; Roulac, 2005, Schulte et al., 2005; Kampamba et al., 2017). Contrastingly, if one purses real estate studies in the United Kingdom (UK), greater emphasis is placed on a classic surveying curriculum, involving an orientation to land disciplines (Roulac, 2002; Jayantha \& Chiang, 2012).

In Africa, real estate education, and the profession at large, is developing (Cloete, 2002; Adewunmi \& Olaleye, 2011; Oloyede \& Adegoke, 2014; Kampamba et al., 2017). In general, the real estate curricula in Africa is diverse and multi-disciplinary in nature. Viruly and Hopkins, (2014: p.11) note that "while there are a number of institutions offering real estate programmes across the continent, there seems to be little consistency in an academically taught body of knowledge and hence there are no standards being achieved". Perhaps this can be explained by the context of real estate markets in emerging markets, which tends to be characterised by dual economies, a lack of market transparency, high levels of uncertainty and the existence of communal/customary and informal rights of ownership. This research notice, therefore, outlines an ongoing research project that aims to examine the academic syllabus taught by universities across Sub-Saharan Africa (SSA). It also provides insight into the multi-disciplinary knowledge base required to enable graduates to succeed in contextually diverse real estate markets.

The objectives of this study are to; explore the existing literature on real estate education and the real estate body of knowledge; assess and understand the differences that exist between the real estate programmes in SSA; and understand the direction that real estate programmes could take in an emerging country context.

\section{Literature Review}

Defining the body of knowledge in real estate is extremely difficult, since there appears to be no clear consensus on the boundary lines of the discipline (Black \& Rabianski, 2003; Jayantha \& Chiang, 2012). Several scholars have attempted to define the body of knowledge in real estate with different claims of being comprehensive. Often the analysis arises from specific philosophical perspectives. For instance, the American approach places a strong emphasis on finance, with the vast majority of real estate academics being housed or affiliated with business colleges (Roulac, 2002). On the other hand, the UK approach mainly focusses on the classic surveying curriculum with strong emphasis on land related disciplines. Typical courses include valuation, law, economics, building construction, planning, management and information technology (Dasso \& Woodward, 1980; Schulte \& Schulte-Daxbök, 2000; Galuppo \& Worzala, 2004). In Brazil, India and China, real estate courses have been organised in a diffused and heterogeneous manner with varying emphasis (Schulte \& Schulte-Daxbök, 2000). Some of the major themes 
include real estate investments, financial systems, economic evaluation, project management, appraisal, land economics, information technology. Thus, real estate courses in these countries can be regarded as adopting a multi-disciplinary approach. The American approach can be justified because real estate development and investment can largely be defined as a business (apart from the residential buildings). The American approach underlines that if one is to understand business (real estate), then scholars ought to be exposed to multiple disciplines of business (Roulac, 2002). However, the UK approach is better at exposing students to the hands-on involvement required for land and buildings. The UK model, therefore, places less emphasis on viewing real estate purely as an investment class.

In response, some scholars have supported the need for a multi-disciplinary approach for real estate programmes that would bring out the advantages of both the American and UK approach and hence develop better graduates (Newell et al., 2004, Musil, 2005; Mooya, 2007). Further, there is also an argument that real estate curricula should bring in line the diverse needs of the student population and the changing work environment instead of rigidly sticking to the traditional (American or UK) approaches (Butler, Guntermann, \& Wolverton, 1998; Schulte \& Schulte-Daxbök, 2000; Roulac, 2002; Galuppo \& Worzala, 2004; Musil, 2005; Schulte et al., 2005). The argument is made that real estate education curricula should include topics ranging from information technology to entrepreneurship, corporate strategy, mortgage securitization, urban form, technological innovation, environmental concerns, globalization, strategic resource and public-private concerns. However, these topics may only be of benefit to the more mature economies located in the Global North and that they have less relevance for emerging markets of the Global South, particularly those located in Africa. In these contexts, factors such as institutional market arrangements, market maturity as well as the political and economic environment, contribute to the increasing inapplicability of many traditional real estate disciplines. Thus, the problems that affect Africa in the real estate industry are different from those in the Global North. The way universities prepare students for real estate profession in Africa must reflect the way graduates will work and solve real estate problems on the African continent.

\section{Methodology}

Previous scholars who have considered this issue have largely carried out their studies using surveys and internet searches. These projects relied on surveys distributed to professionals and academics (Donald, 1996; Black \& Rabianski, 2003; Schulte et al., 2005). This was often complimented with secondary data from educational institutions that teach real estate studies. They also included the verification of data from university websites.

This research explores the existing literature on real estate education to derive an understanding of the body of knowledge in the real estate sector. To achieve the second objective of assessing the differences that exist between programmes, university websites were checked for information concerning their relevant programmes. Real estate academics in different universities in Africa were contacted to provide the researchers with the necessary programme backgrounds. Eight academics from eight universities engaged 
with the researchers and were involved in the survey. The eight universities are: the University of Cape Town and the University of Witwatersrand in South Africa; Copper Belt University in Zambia; the University of Nairobi in Kenya; Ardhi University in Tanzania; Makerere University in Uganda; the Federal University of Technology in Minna, Nigeria; and Kwame Nkrumah University in Ghana. An analysis of the eight universities was conducted and the university courses in real estate were catergorised into eight subcomponents based on the literature (Black \& Rabianski, 2003; Schulte et al., 2005; Harrison \& Manning, 2009; Jayantha \& Chiang, 2012; Boyd et al., 2014). The eight categories include: Business in Real Estate; Law and Taxation; Construction and Technology; Business and Management; Finance and Valuation; Economics; Land Surveying and Environment; and Others. The different courses under each of the eight categories are shown in Table 1 below. 
Table 1: Categorisation of Real Estate Programmes in Sub-Saharan Africa

\begin{tabular}{|c|c|c|c|c|c|c|c|}
\hline Business in RE & $\begin{array}{l}\text { Finance \& } \\
\text { Valuation }\end{array}$ & Law \& Taxation & Economics & $\begin{array}{c}\text { Construction \& } \\
\text { Technology }\end{array}$ & $\begin{array}{c}\text { Land \& } \\
\text { Surveying }\end{array}$ & $\begin{array}{c}\text { Business } \\
\text { Management }\end{array}$ & Others \\
\hline $\begin{array}{ll}\text { - } & \text { Facilities } \\
\text { - } & \text { Property } \\
& \text { Maintenance } \\
\text { - } & \text { Housing } \\
\text { - } & \text { RE Principles } \\
\text { - } & \text { RE Market } \\
& \text { Analysis } \\
\text { - } & \text { RE Management } \\
\text { - } & \text { RE } \\
& \text { Development } \\
\text { - } & \text { Brokerage } \\
\text { Business } \\
\text { Management } \\
\text { - Development } \\
\text { Perspective } \\
\text { - Property } \\
\text { Development } \\
\text { - Estate } \\
\text { Management } \\
\text { - Corporate RE } \\
\text { Management } \\
\text { - RE Marketing \& } \\
\text { Agency } \\
\text { - RE Information } \\
\text { Systems }\end{array}$ & $\begin{array}{ll}\text { - } & \text { Mathematics for } \\
& \text { RE } \\
\text { - } & \text { Valuation } \\
\text { - } & \text { Accounting } \\
\text { - } & \text { Financial } \\
\text { Management } \\
\text { - } \text { Investment } \\
\text { Appraisal \& } \\
\text { Analysis } \\
\text { - Land Taxation } \\
\text { - Value \& Risk } \\
\text { Management } \\
\text { - RE Finance } \\
\text { - Business } \\
\text { - Finance } \\
\text { - Management } \\
\text { Accounting } \\
\text { - Risk \& } \\
\text { Insurance } \\
\text { Practice } \\
\text { - Corporate } \\
\text { Finance }\end{array}$ & $\begin{array}{ll}\text { - } & \text { Elements of the } \\
& \text { Law \& } \\
& \text { Government } \\
\text { - } & \text { Law of Contract } \\
\text { \& Tort } \\
\text { - } & \text { Law of Real } \\
& \text { Property } \\
\text { - } & \text { Business Law } \\
\text { - } & \text { Property } \\
& \text { Dispute } \\
\text { Resolution } \\
\text { - } \text { Commercial } \\
\text { Law } \\
\text { - } \text { Real Estate Law } \\
\text { - } & \text { Labour Law } \\
\text { - } & \text { Property \& } \\
\text { Contract Law } \\
\text { - } \text { Land Law } \\
\text { - } \text { Planning \& } \\
\text { Public Policy } \\
\text { Analysis } \\
\text { - } \quad \text { Landlord Tenant } \\
\text { Law }\end{array}$ & $\begin{array}{ll}\text { - } & \text { Micro-economics } \\
\text { - } & \text { Macro-economics } \\
\text { - } & \text { Agriculture \& } \\
& \text { Economics } \\
\text { - } & \text { Management Land } \\
& \text { Economics } \\
\text { - } & \text { Natural Resource } \\
& \text { Economics } \\
\text { - } & \text { Housing } \\
& \text { Economics\& } \\
& \text { Administration } \\
\text { - } & \text { Econometrics for } \\
& \text { Property Studies } \\
\text { - } & \text { Urban Economics } \\
\text { - } & \text { Property Studies }\end{array}$ & $\begin{array}{ll}\text { - } & \text { Architectural } \\
\text { Drawing \& Design } \\
\text { - } \text { Building } \\
\text { Technology } \\
\text { - } \text { Science \& } \\
\text { Technology in } \\
\text { Development } \\
\text { - } \text { Building Material } \\
\text { \& Finishes } \\
\text { - } \text { Project } \\
\text { Management } \\
\text { - } \text { Measurement } \\
\text { - } \text { Architectural } \\
\text { Studies \& } \\
\text { Construction } \\
\text { - Construction } \\
\text { - } \text { Building Materials } \\
\text { - } \text { Infrastructure \& } \\
\text { Building Services } \\
\text { - Management \& } \\
\text { Structural } \\
\text { Condition Surveys } \\
\text { - } \text { Built Environment } \\
\text { - Free Hand } \\
\text { Sketching }\end{array}$ & $\begin{array}{ll}\text { - } & \text { Physical } \\
\text { Environment } \\
\text { - Environmental } \\
\text { Science } \\
\text { - Environmental } \\
\text { Building Services } \\
\text { - } & \text { Introduction to } \\
& \text { Land Surveying } \\
\text { - } & \text { Elements of Urban } \\
\text { \& Regional } \\
\text { Planning } \\
\text { - Land } \\
\text { Administration \& } \\
\text { Information } \\
\text { Systems } \\
\text { - Environmental } \\
\text { Impact Assessment } \\
\text { \& Audits } \\
\text { - Land Management } \\
\text { \& Policy Studies } \\
\text { - Planning for } \\
\text { Property } \\
\text { Developers } \\
\text { - Urban Land Use \& } \\
\text { Development } \\
\text { - Geographical } \\
\text { Information } \\
\text { Systems } \\
\text { - Land Information } \\
\text { Systems }\end{array}$ & 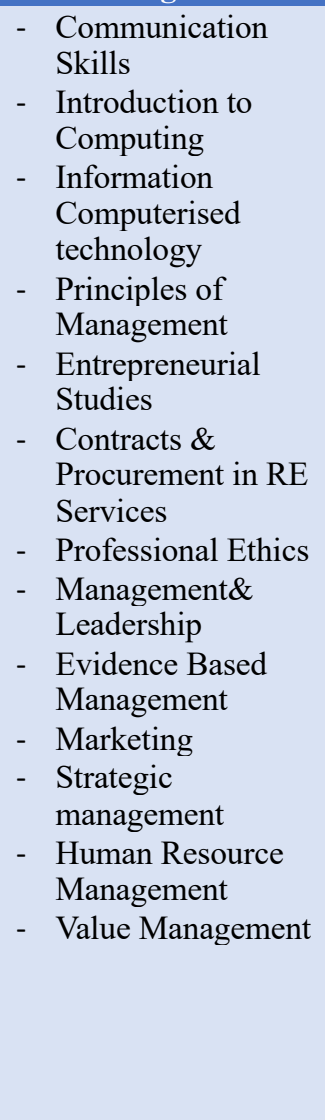 & $\begin{array}{ll}\text { - } & \text { Statistics } \\
\text { - } & \text { Mathematics } \\
\text { - } & \text { Quantitative } \\
& \text { Methods } \\
\text { - } & \text { English } \\
& \text { Language } \\
\text { - } & \text { Research } \\
\text { Methods } \\
\text { - Science \& } \\
\text { Technology in } \\
\text { Development } \\
\text { - Principles of } \\
\text { Agriculture \& } \\
\text { Forestry } \\
\text { - Field Attachment } \\
\text { - Globalisation \& } \\
\text { the Built } \\
\text { environment } \\
\text { - Industrial } \\
\text { Training } \\
\text { - Philosophy } \\
\text { - } \text { HIV/AIDS }\end{array}$ \\
\hline
\end{tabular}


Table 2: Percentages of Subject Categorisation per University

\begin{tabular}{|c|c|c|c|c|c|c|c|c|c|c|c|c|c|c|c|c|c|c|c|c|}
\hline & & & \multicolumn{18}{|c|}{ Categories of Real Estate Courses in SSA } \\
\hline & University & Programme & \multicolumn{2}{|c|}{$\begin{array}{c}1 \\
\text { Business in } \\
\text { RE }\end{array}$} & \multicolumn{2}{|c|}{$\begin{array}{c}2 \\
\text { Finance \& } \\
\text { Valuation }\end{array}$} & \multicolumn{2}{|c|}{$\begin{array}{c}3 \\
\text { Law \& } \\
\text { Taxation }\end{array}$} & \multicolumn{2}{|c|}{$\begin{array}{c}4 \\
\text { Economics }\end{array}$} & \multicolumn{2}{|c|}{$\begin{array}{c}5 \\
\text { Construction } \\
\& \\
\text { Technology }\end{array}$} & \multicolumn{2}{|c|}{$\begin{array}{c}6 \\
\text { Land } \\
\text { Surveying \& } \\
\text { Environment } \\
\end{array}$} & \multicolumn{2}{|c|}{$\begin{array}{c}7 \\
\text { Business \& } \\
\text { Management }\end{array}$} & \multicolumn{2}{|c|}{$\begin{array}{c}8 \\
\text { Others }\end{array}$} & \multicolumn{2}{|c|}{$\begin{array}{c}\text { Total } \\
\text { Number of } \\
\text { Courses }\end{array}$} \\
\hline & & & No. & $\%$ & No. & $\%$ & No. & $\%$ & No. & $\%$ & No. & $\%$ & No. & $\%$ & No. & $\%$ & No. & $\%$ & No. & $\%$ \\
\hline 1 & $\begin{array}{l}\text { University of } \\
\text { Nairobi }\end{array}$ & $\begin{array}{l}\text { Bachelor of } \\
\text { Real Estate }\end{array}$ & 4 & $7 \%$ & 10 & $18 \%$ & 5 & $9 \%$ & 9 & $16 \%$ & 6 & $11 \%$ & 8 & $14 \%$ & 6 & $11 \%$ & 8 & $14 \%$ & 56 & $100 \%$ \\
\hline 2 & $\begin{array}{l}\text { University of } \\
\text { Witwatersrand }\end{array}$ & $\begin{array}{l}\text { BSc in } \\
\text { Property } \\
\text { Studies }\end{array}$ & 7 & $23 \%$ & 7 & $23 \%$ & 2 & $7 \%$ & 4 & $13 \%$ & 3 & $10 \%$ & 2 & $7 \%$ & 3 & $10 \%$ & 2 & $7 \%$ & 30 & $100 \%$ \\
\hline 3 & $\begin{array}{l}\text { University of } \\
\text { Cape Town }\end{array}$ & $\begin{array}{l}\text { BSc } \\
\text { Property } \\
\text { Studies }\end{array}$ & 1 & $2 \%$ & 6 & $14 \%$ & 9 & $21 \%$ & 9 & $21 \%$ & 4 & $10 \%$ & 0 & $0 \%$ & 6 & $14 \%$ & 7 & $17 \%$ & 42 & $100 \%$ \\
\hline 4 & $\begin{array}{l}\text { Makarere } \\
\text { University }\end{array}$ & $\begin{array}{l}\text { Bachelor of Real Estate } \\
\text { Business Management }\end{array}$ & 6 & $19 \%$ & 6 & $19 \%$ & 2 & $6 \%$ & 2 & $6 \%$ & 1 & $3 \%$ & 3 & $10 \%$ & 6 & $19 \%$ & 5 & $16 \%$ & 31 & $100 \%$ \\
\hline 5 & $\begin{array}{l}\text { Ardhi } \\
\text { University }\end{array}$ & $\begin{array}{c}\text { BSc in Real Estate } \\
\text { Finance and Investment }\end{array}$ & 6 & $10 \%$ & 14 & $22 \%$ & 5 & $8 \%$ & 4 & $6 \%$ & 5 & $8 \%$ & 7 & $11 \%$ & 7 & $11 \%$ & 15 & $24 \%$ & 63 & $100 \%$ \\
\hline & & $\begin{array}{c}\text { BSc in Property and } \\
\text { Facilities Management }\end{array}$ & 12 & $19 \%$ & 7 & $11 \%$ & 6 & $10 \%$ & 3 & $5 \%$ & 7 & $11 \%$ & 6 & $10 \%$ & 10 & $16 \%$ & 12 & $19 \%$ & 63 & $100 \%$ \\
\hline 6 & \begin{tabular}{|l|l|} 
Copper Belt \\
University
\end{tabular} & $\begin{array}{l}\text { BSc in Real } \\
\text { Estate Studies }\end{array}$ & 3 & $10 \%$ & 7 & $23 \%$ & 3 & $10 \%$ & 4 & $13 \%$ & 4 & $13 \%$ & 2 & $6 \%$ & 2 & $6 \%$ & 6 & $19 \%$ & 31 & $100 \%$ \\
\hline 7 & $\begin{array}{l}\text { Federal } \\
\text { University of } \\
\text { Technology in } \\
\text { Minna }\end{array}$ & $\begin{array}{l}\text { B.Tech in Estate } \\
\text { Management }\end{array}$ & 6 & $8 \%$ & 13 & $17 \%$ & 9 & $12 \%$ & 9 & $12 \%$ & 14 & $18 \%$ & 9 & $12 \%$ & 6 & $8 \%$ & 11 & $14 \%$ & 77 & $100 \%$ \\
\hline 8 & $\begin{array}{l}\text { Kwame } \\
\text { Nkrumah } \\
\text { University }\end{array}$ & $\begin{array}{l}\text { BSc in Estate } \\
\text { Management }\end{array}$ & 7 & $14 \%$ & 10 & $20 \%$ & 9 & $18 \%$ & 2 & $4 \%$ & 6 & $12 \%$ & 3 & $6 \%$ & 5 & $10 \%$ & 8 & $16 \%$ & 50 & $100 \%$ \\
\hline
\end{tabular}


Results from the desktop research (Table 2) reveal that universities in SSA have either taken on the UK approach or the American approach. For instance, the University of Nairobi has the majority of their courses in Land Surveying. Whilst the Federal University of Technology in Minna tends to be focused on construction and technology. Other universities in SSA have adopted the American approach placing a strong emphasis on finance and investment.

The subsequent research objective concerns understanding the direction that real estate programmes could take in an emerging country context. This will be achieved via a survey because this method of data collection is relatively inexpensive, convenient and often easier to find statistically significant results than other data gathering methods. Survey questionnaires were distributed to the attendees of the 2018 African Real Estate Society (AfRES) Conference in Abeokuta; Nigeria. Furthermore, a similar questionnaire has also been applied by the Latin American Real Estate Society. The intention being to provide a comparison between programmes in SSA and in Latin America; regions characterised by emerging real estate markets.

The survey comprised open and closed ended questions. Of the questionnaires administered at the conference, 100 responses were retrieved from AfRES. The questionnaire comprised questions that would help show the direction that real estate programmes can take in an emerging country context. Attendees were asked to rank different topics according to perceived importance in educational programmes. This includes risk and return analysis, discounted cash flow analysis, real estate market modelling-demand and supply analysis, yield calculation and forecasting, real estate market cycles and forecasting, government policy impact on real estate, appraisal methodology and techniques, analysis of site characteristics, financial market cycles and forecasting, urban development and growth analysis, macroeconomic cycles and forecasting, commercial location theory, lease analysis, commercial real estate location requirements, and land use regulations. The data collected from the survey conducted in Nigeria is yet to be analysed, and the survey from Latin America has not yet been completed.

Moving forward the survey results will be correlated against the preliminary desktop research (shown in Table Two). Following this, the results from Latin America Real Estate Society's survey will be compared with that of the questionnaires collected at the recent AfRES Conference in Nigeria. Results will be analysed and compared to help define the direction of real estate programmes in the emerging country context.

\section{Conclusion}

Previous research suggests that apart from core competencies, real estate programmes should incorporate a set of general educational outcomes required for real estate professionals. The important issue is that curricula should attempt to reflect the market context in which they are delivered. While countries that are characterised by mature real estate markets tend to place a strong emphasis on investment and finance, this is not the case for countries characterised by more opaque, emerging markets. This research suggests that there is evidence that real estate programmes in SSA tend to 
find an appropriate balance between subjects of a social and financial nature. However, the research also suggests that it is difficult to identify strong similarities between real estate programmes offered in SSA. The outcome of the combined African and Latin American research aims to show whether commonalities exist between programmes across these two continents and whether conclusions can be drawn for programmes delivered in an emerging country context.

\section{References}

Adewunmi, Y. \& Olaleye, A. (2011). Real Estate Research Directions and Priorities for Nigerian Institutions. Journal of Real Estate Practice and Education, 14(2), pp.125-140.

Black, R. \& Rabianski, J. (2003). Defining the Real Estate Body of Knowledge: A Survey Approach. Journal of Real Estate Practice and Education, 6(1), pp.33-54.

Boyd, D., Amidu, A.-R. \& Smith, M. (2014). Developing a Practice-Based Body of Real Estate Knowledge: A Delphi Study. Journal of Real Estate Practice and Education, 17(2), pp.139-167.

Butler, J., Guntermann, K. \& Wolverton, M. (1998). Integrating the Real Estate Curriculum. Journal of Real Estate Practice and Education, 1(1), pp.51-66.

Cloete, C.E. (2002). Progress in Real Estate Education in South Africa. Property Management, 20(5), pp.369-382.

Dasso, J. \& Woodward, L. (1980). Real Estate Education: Past, Present and Future - the search for a discipline. Real Estate Economics, 8(4), pp.404-416.

Donald, E. (1996). The Current Body of Knowledge Paradigms Used in Real Estate Education and Issues in Need of Further Research. Journal of Real Estate Research, 12(2), pp.229-236.

Galuppo, L. \& Worzala, E. (2004). A Study into the Important Elements of a Masters Degree in Real Estate. Journal of Real Estate Practice and Education, 7(1), pp.25-42.

Newell, G., Worzala, E., Mc Allister, P. \& Schulte, K. (2004). An International Perspective on Real Estate Research Priorities. Journal of Real Estate Portfolio Management, 10(3), pp.161-170.

Harrison, D. \& Manning, C. (2009). Characteristics of Recent Real Estate Research: 2000-2006. Journal of Real Estate Practice and Education, 11(2), pp.109-126.

Jayantha, W.M. \& Chiang, Y.H. (2012). Key Elements of Successful Graduate Real Estate Education in Hong Kong: Students' Perspective. Journal of Real Estate Practice and Education, 15(2), pp.101-128.

Kampamba, J., Tembo, E. \& Nkwae, B. (2017). An Evaluation of the Relevance of Real Estate Curricula in Botswana. Property Management, 35(3), pp.275-305.

Mooya, M.M. (2007). The Impact of Property Education on Property Research in South Africa: A Review. RICS Research Paper Series, 7(6), pp.9-32.

Musil, T. (2005). Integrating Business School Curricular Resources into Real Estate Practitioner Professional Development. Journal of Real Estate Practice and Education, 8(1), pp.133-149. 
Oloyede, S.A. \& Adegoke, O.J. (2014). Relevance of Real Estate Education to Practice in Nigeria. Journal of Land Use and Development Studies, $3(1)$, pp.50-60.

Roulac, S.E. (2002). Requisite Knowledge for Effective Property Involvements in The Global Context. In Real Estate Education Throughout the World: Past, Present and Future. Springer: London. pp.3-24.

Schulte, K.-W. \& Schulte-Daxbök, G. (2000). Real Estate Education Throughout the World. In American Real Estate Society Annual Meeting: March 2000, Santa Barbara, California.

Schulte, K.-W., Schulte-Daxbök, G., Holzmann, C., \& Wiffler, M. (2005). Internationalisation of Real Estate Education. In European Real Estate Society Conference: June 2005, Dublin, Ireland.

Viruly, F., \& Hopkins, N. (2014). Unleashing Sub Saharan Africa Property Markets. Report for RICS: London. 